\title{
La prensa satírica, las guerras y la configuración del enemigo en el siglo XIX: el caso de Paraguay Illustrado (Rio de Janeiro, 1865) y El Barbero (Santiago de Chile, 1879)
} \author{
the case of Paraguay Illustrado (Rio de Janeiro, 1865) \\ and El Barbero (Santiago de Chile, 1879) \\ Silvina Sosa Vota \\ Programa de Doctorado en Historia \\ Universidad de Santiago de Chile \\ silvina.sosa.vota@gmail.com
}

Satirical press, wars and the representation of the enemy in the XIX century:

\section{Resumen}

El objetivo de este artículo es analizar, de forma comparada, las representaciones visuales de dos periódicos satíricos que circularon durante conflictos bélicos. Por un lado, Paraguay Illustrado, publicado en 1865, primer año de la Guerra de la Triple Alianza, en la ciudad de Rio de Janeiro y por el otro, El Barbero de Santiago de Chile, que salió a la luz a finales del primer año del conflicto del Pacífico (1879). Se sostiene como hipótesis que, si bien la prensa satírica se caracterizó por posicionarse de forma crítica con el poder y contra los poderosos, en tiempos de guerra actuó como medio de difusión de ideas e imágenes en clave nacionalista basada en la inferiorización de la alteridad. El discurso sobre lo propio y lo otro representado en sus páginas, reprodujo una perspectiva maniquea de la guerra, que ensalzó al yo en detrimento de una desvalorización del enemigo.

Palabras clave: caricaturas; identidad, alteridad, guerras sudamericanas, periódicos.

\begin{abstract}
The main objective of this article is to analyse, in a comparative perspective, the visual representations published in two satirical papers during war times. The sources will be, in the first place, Paraguay Illustrado published in 1865, first year of Triple Alliance War, in the city of Rio de Janeiro and, in second place El Barbero from Santiago de Chile, issued by the end of the first year of the Pacific War (1879). The hypothesis is that, despite the press was characterized by critical posicion against political power and, in wartimes it acted as source of representation about nationalist ideas and images based on the lower image of the enemy. The speech about identity and otherness on its pages, reproduced a Manichean perspective about war that exalted the self-image and devaluated the enemy's image.
\end{abstract}

Key words: caricatures; identity; otherness, South American wars, papers. 


\section{Guerras y prensa de caricaturas}

Para comerse al mendrugo de Paraguai, se unieron en una sola tarasca tres potencias, la Arjentina, el Brasil i la Oriental.

Siguieron luego la moda el Perú i Bolivia, formando una alianza en tratado con un enemigo que no nombraron, pero se dejaba adivinar. [...]

Decididamente lo sud-americanos hemos fundado i llevamos adelante el principio de que no se puede hacer la guerra sin aliados, es decir, dos, cuatro o cuantos mas se pueda contra uno.

El Barbero, No 27 de diciembre de 1879, p. 1

Durante la segunda mitad del siglo XIX, el espacio sudamericano fue escenario de dos conflictos bélicos de enormes proporciones que definieron el tablero geopolítico de la región hasta la actualidad. En la región de la cuenca del Plata, Brasil, Argentina y Uruguay se aliaron contra Paraguay en una contienda que tuvo sus inicios en 1864 y culminó en 1870. Nueve años después, del lado del océano Pacífico, Chile se enfrentó a Perú y Bolivia hasta 1884. Estas guerras movilizaron miles y miles de personas - muchas de ellas perdieron su vida y otras tantas resultaron heridas-, exigieron arsenales e infraestructura bélica, que en los inicios no siempre estaban tan disponibles en los países, y consumieron recursos económicos en gran magnitud, generando deudas y compromisos financieros a futuro. Tanto la guerra del Pacífico como la del Paraguay, fueron eventos que demandaron enormes esfuerzos de las sociedades que se vieron involucradas.

Paralelamente, desde la década de 1850 , de forma general las publicaciones periódicas en la región habían aumentado cuantitativa y cualitativamente. Existían las condiciones tecnológicas y culturales para el desarrollo de una prensa, que, si bien todavía enfrentaba múltiples problemáticas, tuvo estímulos suficientes para acumular experiencias, unas más exitosas que otras, pero que caminaban hacia la consolidación de la actividad periodística.

Castagneto afirma que "así como de pronto debieron crearse nuevos batallones, surgieron también nuevos periódicos cuyo fin era servir a la causa de la guerra" (2015: 19). En este sentido, la guerra del Plata y la del Pacífico generaron impulsos adicionales para la puesta en circulación de un caudal mayor de información al respecto de lo que estaba ocurriendo[1].

Las sociedades como las de Santiago de Chiley Rio de Janeiro, ambas capitales lejanas a los teatros principales de los enfrentamientos, demandaban conocer sobre lo que ocurría a cientos de kilómetros de distancia, puesto que los esfuerzos generados por la guerra, a nivel estatal y social, hacían que no fuera un asunto ajeno para las poblaciones. Los periódicos llevaron al cotidiano de las personas 
información actualizada sobre lo que ocurría en tierras distantes.

Adiferencia deguerrasanteriores, la disponibilidad derecursostécnicospermitióque el enfrentamiento contra Paraguay fuera el primer conflicto armado internacional en recibir una cobertura visual en la prensa (Toral, 2001). La cercanía temporal con la contienda del Pacífico, hace presumir que la representación visual periodística y cotidiana de los hechos bélicos iniciados en 1879 hayan supuesto un hito en el mismo sentido.

Dentro del espectro de publicaciones periódicas en circulación, un género en particular interesa a efectos de este trabajo: la prensa satírica. Estos periódicos, con fuerte presencia en gran parte de las ciudades más relevantes de Sudamérica, tenían la particularidad de presentar imágenes como eje central de su proyecto editorial. La mayoría de ellas pertenecían al género de la caricatura política. En tiempos de guerra estos periódicos sufrieron estímulos coyunturales para el aumento de su circulación y popularización.

Considerando lo hasta aquí expuesto, el objetivo de este artículo es analizar, de forma comparada, dos periódicos satíricos en particular que circularon durante conflictos bélicos. Por un lado, Paraguay Illustrado, publicado en 1865, primer año de la Guerra de la Triple Alianza, en la ciudad de Rio de Janeiro y por el otro, El Barbero de Santiago de Chile, que salió a la luz a finales del primer año del conflicto del Pacífico (1879).

Pero ¿por qué comparar estas dos fuentes periódicas de ciudades y tiempos distintos? Liliana
Brezzo sugiere que "la historia de la guerra se robustece si se hace desde una perspectiva comparada, aunque cada historia sea un cosmos en sí misma" (Whigham et al., 2021: 15). Siguiendo esta idea, no se consideran como equivalentes las dos guerras supra mencionadas pues cada una tuvo particularidades únicas, pero se entiende que al compararlasy, específicamente, al contrastar dos versiones de un mismo artefacto cultural presente en ambos conflictos, podrían observarse aspectos regionales y compartidos.

En este sentido, se ha constatado que la prensa satírica fue un fenómeno presente tanto en Rio de Janeiro como en Santiago de Chile y que, además, tenían condiciones de posibilidad bastante similares. En ambos espacios se miraba como modelo de referencia los periódicos de caricaturas europeas (Knauss et al., 2011; Montealegre, 2008; Toral, 2001) . Así, estos formatos interactuaron con cada coyuntura local específica convirtiéndose en producciones originales, pero con varios puntos de contacto entre sí. Además, la misma técnica litográfica era la empleada en la producción de estos proyectos, lo cual les proporcionaba características similares.

Por otro lado, se considera que ambas guerras referidas en este trabajo fueron estructurantes en materia de identidad nacional para todos los Estados involucradosy, especialmente para Chile y Brasil. Desde estos espacios, los conflictos tuvieron una gran cobertura mediática y se busca observar a partir de dos fuentes particulares y específicamente en las imágenes que éstas vehicularon, los discursos identitarios que presentaron. Es decir, ¿cómo se representó la idea del nosotros 
en las caricaturas? ¿Cómo fueron caracterizados los otros? ¿Cómo se configura la alteridad?

Se sostiene como hipótesis que, si bien la prensa satírica se caracterizó por posicionarse de forma crítica con el poder y contra los poderosos, en tiempos de guerra actuó como medio de difusión de ideas e imágenes en clave nacionalista basada en la inferiorización de la alteridad. El discurso sobre lo propio y lo otro representado en sus páginas, reprodujo una perspectiva maniquea de la guerra, que ensalzó al yo en detrimento de una desvalorización del enemigo.

\section{La prensa satírica y las caricaturas.}

Dentro del universo de la cultura impresa[2] decimonónica, la prensa satírica con caricaturas ocupó un lugar particular. A diferencia de los mapas, estampas, láminas y otros tipos de soportes, estas publicaciones estuvieron determinadas por el diario suceder de los acontecimientos, destacándose su labor informativa desde la perspectiva irreverente que las caracterizaba.

De acuerdo con Claudia Román, estos artefactos culturales pueden definirse como:

[...] publicaciones con rasgos formales propios, cuya elección se orienta hacia la búsqueda de determinados efectos y que se relaciona fluida y explícitamente, a través de diversas formas de intertextualidad (alusión, cita, parodia) con otros discursos. Así, la prensa satírica supone la articulación de palabras e imágenes impresas en una publicación cuya finalidad se quiere inmediata y eficaz en su capacidad de actuar sobre la realidad. (Román, 2010: 18)

Según Toral, las publicaciones satíricas presentaban un humor basado en la sátira de las "costumes, dos políticos, da economia, da igreja e, principalmente, de autoridades e do governo" (2001:60) . En otras palabras, atacaban a los poderosos y al poder. Sobre la sátira, Montealegre agrega que constituye "una representación crítica, irreverente y burlesca", y refuerza que se relaciona con la realidad debido a que "tiene un anclaje en ella y propone asociaciones pertinentes con dichos o hechos reales" (2008: 13). En este sentido, los periódicos del género aquí abordado no pueden separarse de su coyuntura, pues son actores de esta, la interpelan, la representan a través de textos e imágenes.

Estos periódicos particulares del sigloXIX "colocan al lector en contacto directo con una época y sus representaciones" (Silva, 2017: 67). Estas permiten ver cómo las sociedades organizan el mundo que las rodea, cómo jerarquizan las relaciones que se vinculan en él y cómo se configuran las identidades en juego (Chartier, 2011). Además, según Robert Darnton, las versiones impresas de los discursos, y fijadas sobre papel, hilan en líneas narrativas las ideas ya presentes en la sociedad, contribuyendo a la creación de sentido de la realidad con la cual las representaciones dialogan (Darnton, 2008: 287).

Considerando esto, las imágenes de la prensa satírica pueden ser entendidas como representaciones, y como tales, actuarían como la puerta de acceso a las formas de organizar la realidad 
que los contemporáneos tenían en un momento específico desde un lenguaje muy peculiar. Así, son un camino que posibilita entrar al universo de las luchas simbólicas de las sociedades pretéritas.

Las caricaturas, forma principal de las imágenes de las publicaciones que ocupan a este trabajo, son entendidas como una forma particular de ordenamiento del mundo social pues son vehículos interpretativos de la realidad (Ibarra, 2009). Desde la "libertad para traducir los conceptos y símbolos" (Gombrich, 1998: 129) configuran un orden particular del universo inmediato con el cual dialogan. Volcadas principalmente al humor político, son representaciones visuales capaces de mostrar las luchas de poder que se trababan en una época determinada. Deformando, animalizando, exagerando y recurriendo a otras tantas técnicas de su “arsenal", se pensaron como armas de ataque del escenario con el que dialogaban.

La guerra del Paraguay y la guerra del Pacífico no fueron eventos que a la prensa satírica le hayan sido indiferentes, sino más bien, todo lo contrario. El conflicto se dio también en la prensa pues ella se constituyó como un escenario de enfrentamientos (Silveira, 2015). Como afirma Chartier, "los enfrentamientos fundados en la violencia bruta, en la fuerza pura, se transforman en luchas simbólicas, o sea en luchas que tienen las representaciones por armas y por apuestas" (Chartier, 2011:20). Los periódicos satíricos de la época fueron, por lo tanto, lo que Luc Capdevila llama de "formas simbólicas de la movilización" (2020: 121). En este sentido, al respecto de uno de los conflictos bélicos estudiados, pero aplicable también a la otra, Ibarra sostiene que
Mientras miles de hombres combatían en los campos de batalla de la Guerra del Pacífico, en las redacciones de los periódicos de sátira, escritores, poetas y dibujantes chilenos blandieron sus afilados lápices y pinceles para combatir a su manera a sus adversarios. (Ibarra, 2016: 91)

Las largas contiendas de un margen y otro de Sudamérica, fueron "el marco para que la circulación de palabras e imágenes impresas contribuyera[n] con el examen y redefinición de las identidades nacionales" en juego (Román, 2016:132) [3]. En estos contextos, la prensa tendió a "imponer imágenes estereotipadas y negativas del enemigo como un reflejo opuesto de una imagen propia positiva" (Johansson, 2017: 34), dándole sustancia visual a las ideas en circulación en la época que el contexto nacionalista propiciado por la guerra alentó. Por esto, se sostiene las caricaturas que vieron la luz durante estos conflictos modelaron ideas y percepciones sobre los personajes y hechos protagonistas de los sucesos (Ibarra, 2016: 16).

Se entiende, por tanto, que la prensa satírica y las imágenes caricaturales vehiculadas en sus páginas son una fuente importantísima para conocer "aspectos culturales, sociales y políticos, no solo del conflicto, sino también de las sociedades envueltas en el" (Johansson, 2017: 25). En este sentido, el estudio de las identidades, tanto propias como ajenas y sus representaciones son un tema pasible de análisis desde esta perspectiva. Además, estudiar contiendas como la de la Guerra de la Triple Alianza y la del Pacífico desde esta particular producción visual, permite elevar las dimensiones del conflicto que tradicionalmente han sido 
relegadas por el protagonismo de las vertientes económicas, políticas, militares y diplomáticas de estos estudios (Cid, 2011; McEvoy, 2012).

\section{Las fuentes}

Para estudiar estas características destacadas anteriormente, se recurrirá al análisis de parte de la producción de la prensa con caricaturas del siglo XIX a partir de dos hebdomadarios en particular.

\section{Imagen 1 - Paraguay Illustrado}

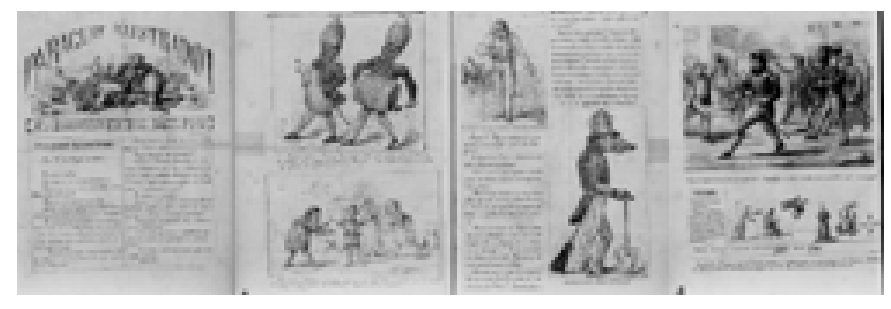

Paraguay Illustrado, No 5, 27 de agosto de 1865, pp. 1-4, Hemeroteca Digital de la Biblioteca Nacional de Rio de Janeiro.

Paraguay Illustrado: jornal pamphicoeomologico, asneirotico, burlesco e galhofeiro fue un periódico de la entonces capital del Imperio de Brasil, que publicó 13 números durante julio y octubre de 1865. Este semanario comenzó circulando los domingos, pero los últimos números lo hacían los días jueves. Su formato era de cuatro páginas que medían 32 por 23 centímetros. El título del proyecto editorial comunicaba explícitamente sus propósitos: ilustrar sobre los sucesos que ocurrían en Paraguay.
Fue impreso en la litográfica de "d. Riscardo", ubicada en la calle San Francisco de Paula, No 1 y utilizaba esta técnica[ [4] en auge en la segunda mitad del siglo XIX (Beretta García, 2012), para la impresión de la totalidad sus páginas. La litografía no solía incluir letras tipografiadas en las páginas que presentaban imágenes, por un tema de costos. Por ello, las publicaciones que hacían uso de la técnica de impresión litográfica solían alternar técnicas quedando separadas en la presentación final las páginas con texto y las de representaciones visuales. No obstante, Paraguay Illustrado como forma de solucionar este asunto, presentabas sus partes textuales con caligrafía manuscrita, pudiendo ser incluida dentro de la misma piedra litográfica en que se insertaba la imagen. Esto fue sin dudas, un rasgo distintivo de la publicación.[5]

En las páginas del periódico no existe mención alguna sobre las personas que estarían por detrás del proyecto editorial. Sin embargo, Mauro César Silveira apunta que el posible caricaturista autor de las imágenes sería Rafael Mendes de Carvalho, sobre quien destaca que fue alumno del renombrado pintor Manuel de Araújo PortoAlegre (Silveira, 2015:57).

Por otro lado, El Barbero:periódico semanal, pelador, de buen humor, caricaturero ilibre hablador fue una publicación de Santiago de Chile que contó con 10 ediciones que salieron a la luz los sábados entre el mes de octubre y el de diciembre del año 1879. La publicación adoptó ese particular nombre que alude a una profesión, entendiéndola como un sinónimo de "hacer ver". Al igual que un barbero que afeita un rostro y devela facciones y rasgos, 
este periódico se entendía como revelador de una realidad. De esta forma, El Barbero habría nacido con la intencionalidad de mostrar a su público lector los verdaderos rostros las personas que se sentaran en su silla y pasaran por sus navajas.

Imagen 2 - El Barbero

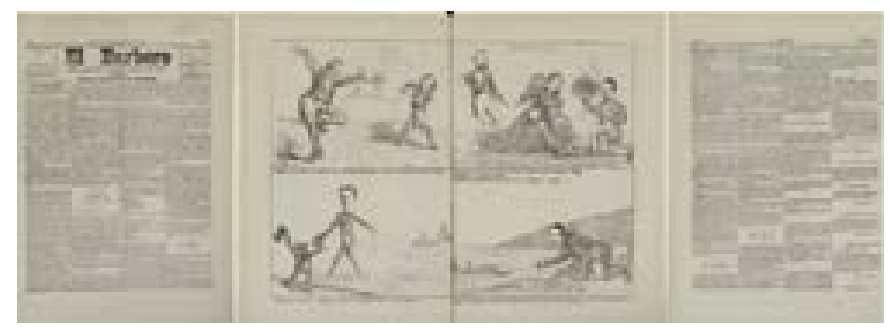

El Barbero, No 1, 18 de octubre de 1879, pp. 1-4, Biblioteca Nacional Digital de Chile

Al igual que Paraguay Illustrado, contaba con cuatro páginas, extensión de bastante frecuencia entre los periódicos del género de la época. De estas, dos eran de texto (la primera y última) y dos contenían imágenes (las centrales). En este caso las secciones textuales eran tipografiadas. Taly como puede apreciarse en la Imagen 2, estaban claramente delimitadas las secciones visuales y las escritas. Pero, al incluir texto en las caricaturas, se hacía de forma manual.

Según figura en su portada, el director y propietario era D. Gajardo. De los ilustradores hasta el momento no se tiene noticia, pues ninguna de las imágenes tiene firma. No sería raro que el propio Gajardo sea el ilustrador, pero no se ha encontrado información sobre esta persona para poder confirmar o desmentir. Era impreso en la calle Bandera No 24.
Se desconoce por qué motivo se dejó de editar el 27 de diciembre de 1879 o si tuvo una segunda época[6]. De cualquier manera, la corta duración no sería una excepción, pues varios títulos de la prensa chilena y brasileña de la época no alcanzaban ni media docena de ediciones[ $[7]$. La anormalidad fueron los periódicos satíricos con varios años de circulación continua.

A pesar de la distancia geográfica y temporal de las publicaciones recién presentadas ambas compartieron ciertas formas y tonos que las hacen pasibles de comparación. El carácter jocoso, las imágenes irreverentes, la postura combativa y el espíritu crítico atraviesan todas las páginas.

Ambos proyectos editoriales nacieron en los primeros momentos de los conflictos anteriormente referidos: Paraguay Illustrado circula el primer año de la Guerra de la Triple Alianza (1865) al igual que El Barbero que lo hace en referencia a la del Pacífico (1879). Este dato es no menor, puesto que, en los dos casos, los albores de la guerra levantaron un ánimo extendido entre la población de los países, que, con el pasar de los años fue apagándose. En instancias iniciales, el horizonte del final se veía próximo, pero esta línea fue corriéndose cada vez más lejos con el pasar de los meses.

En el caso de Brasil, hacia la segunda mitad de 1865, los aliados estaban frenando la avanzada paraguaya hacia el sur[8] y comenzaban a acumulaban algunas victorias en su haber, como el Combate de Riachuelo (11 de junio de 1865) o la Batalla de Yatay (17 de agosto de 1865). Del lado chileno, en 1879 habían tenido lugar enfrentamientos que posteriormente acabaron tomando 
dimensiones épicas en la cultura popular, como el Combate Naval de Iquique (21 de mayo de 1879), que si bien fue derrota chilena, la actitud heroica de Arturo Prat servirá como símbolo de valentía chilena. El 8 de octubre de 1879, se dio otro gran triunfo para las fuerzas chilenas: el Combate Naval de Angamos, en el cual se capturó el monitor peruano Huáscar, evento con repercusiones hasta la contemporaneidad. En suma, tanto uno como otro periódico mencionado están inmersos en eventos que sirvieron de estímulo para el apoyo a la causa nacional.

\section{Las representaciones de los otros}

Matallana sostiene que la caricatura, por su propia naturaleza, ejerce una superioridad sobre el grupo o individuo objetivo de la imagen, reforzando estereotipos de sí y de los otros. La lógica de las publicaciones que pusieron a circular estas representaciones definió, de esa forma, una configuración particular de la identidad, respondiéndose a la pregunta del “quiénes somos?”. Cómo consecuencia, a través de las críticas o de las distancias pautadas, se delineaba también la idea del otro (Matallana, 2010: 19). En este sentido, este trabajo se pregunta ¿cómo se configura el otro de Brasil? ¿Y la alteridad chilena?

Tanto Paraguay Illustrado como El Barbero fueron muy prolíficos en establecer visualmente estas dialécticas identitarias. Estos periódicos representaron un Paraguay y una alianza de Perú y Bolivia respectivamente, juzgados desde la oposición de lo que no se quería ser, de los antivalores de lo propio.

\section{1 ¿Cómo es la alteridad de Brasil?}

Imagen 3 - Condecoración

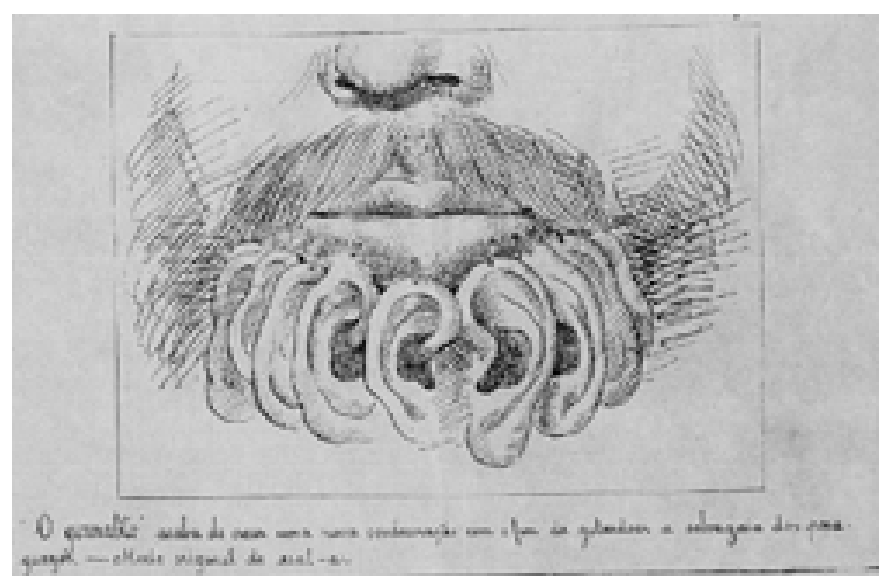

Paraguay Illustrado, No 2, 6 de agosto de 1865, p. 3, Hemeroteca Digital de la Biblioteca Nacional de Rio de Janeiro.

"El generalito acaba de crear una nueva condecoración con el fin de galardonar la salvajería de los paraguayos - Modelo original de usarlo"[9]

En la segunda edición del periódico carioca, se publica la Imagen 3, la cual mostraría una supuesta nueva forma de distinguir a las personas con méritos loables que Francisco Solano López (llamado de Generalito), presidente de Paraguay, habría intentado imponer. El dibujo muestra la parte inferior de un rostro humano masculino de cuyo labio inferior cuelgan casi una decena de orejas humanas enganchadas en la piel como si fueran medallas. Estas orejas con función inusual son juzgadas, según indica el pie de imagen (que cumple la función de explicarla)[10], como síntoma de salvajería. Lo que distinguiría y lo que querría mostrar un paraguayo exitoso, es parte 
del cuerpo de otro ser humano en el suyo, llegando a la frontera de prácticas antropofágicas. Los paraguayos son, entonces, representados como salvajes y como tales peligrosos, partiendo por el conductor de este pueblo.

Además de salvajes, los paraguayos serían también, según Paraguay Illustrado, ignorantes. La Imagen 4 representa un supuesto proyecto para dejar para la posteridad las acciones de López. Se observa, en un espacio aparentemente urbano, una pila de cadáveres amontonados formando una estructura piramidal en cuyo vértice se coloca una bandera que, por contexto, se entiende como paraguaya. El ambiente lúgubre de la imagen lo indica la noche cerrada que sugiere la oscuridad del cielo y los cuervos que revolotean el proyecto de monumento y que llegan a posarse en mástil de la bandera.

Imagen 4 - Proyecto de monumento

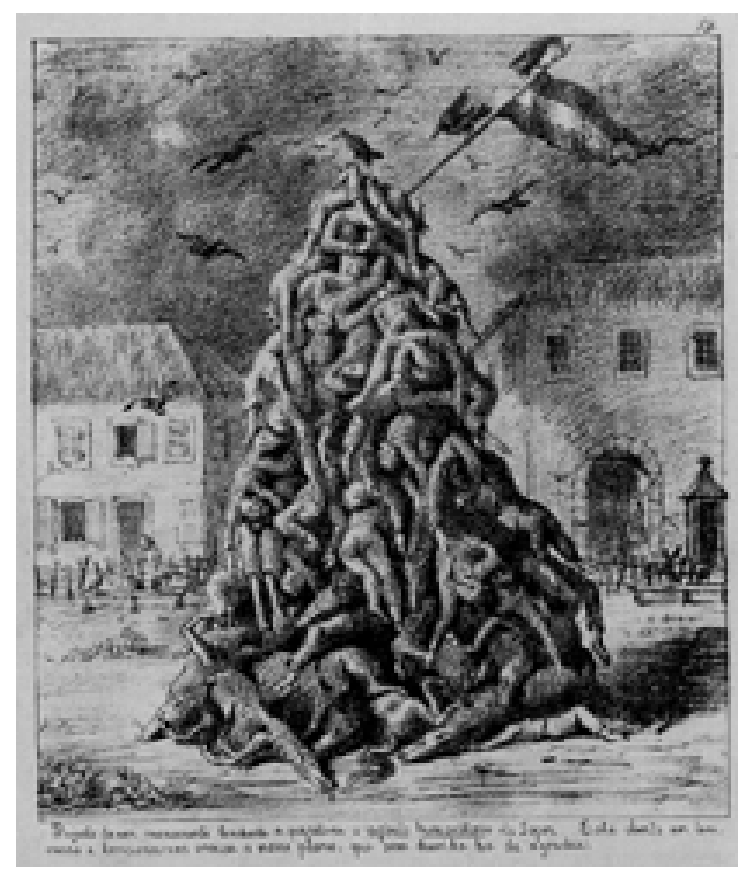

Paraguay Illustrado, No 3, 13 de agosto de 1865, p. 4, Hemeroteca Digital de la Biblioteca Nacional de Rio de Janeiro.

"Proyecto de monumento tendiente a perpetuar el espíritu humanitario de López. Está abierto un concurso y tenemos la intención de enviar nuestro plano, que sin duda han de agradar”.

Haciendo foco en elgrueso del monumento, decenas de restos morales humanos yacen unos encima de los otros. Ninguno de ellos porta zapatos y sus ropas son muy sencillas y prácticamente iguales en todos los cuerpos. En sus rostros cadavéricos, que son igualmente indistintos, no es posible reconocer individualidades. Son cuerpos, sin personalidad específica, y sin ninguna otra característica distintiva más que su nacionalidad paraguaya. Hacia la base de esta pila mortal, a diferencia del resto de la composición, se observan cuerpos igualmente sin vida, pero de burros. Ellos soportan la construcción vertical y se entrelazan con cadáveres humanos a medida que se va avanzando hacia arriba. Estos animales son utilizados en esta imagen para simbolizar ignorancia, falta de inteligencia.

En el caso de esta representación, el texto que la acompaña cumple la función de ironizar desde el contraste generado por el mensaje escrito y el visual. Por un lado, la nota indica que el foco de la imagen es una construcción pensada para celebrar el "espíritu humanitario" de Francisco Solano López, idea que choca con la presentación visual de lo inhumano: la muerte de su gente, la despreocupación por su pueblo. Los paraguayos son el respaldo de su presidente y su mala elección 
se justifica por la confusión de estos con los asnos de la base. La autoridad inhumana tiene así su fundamento: un pueblo ignorante.

\section{Imagen 5 - Los niños van a la guerra}

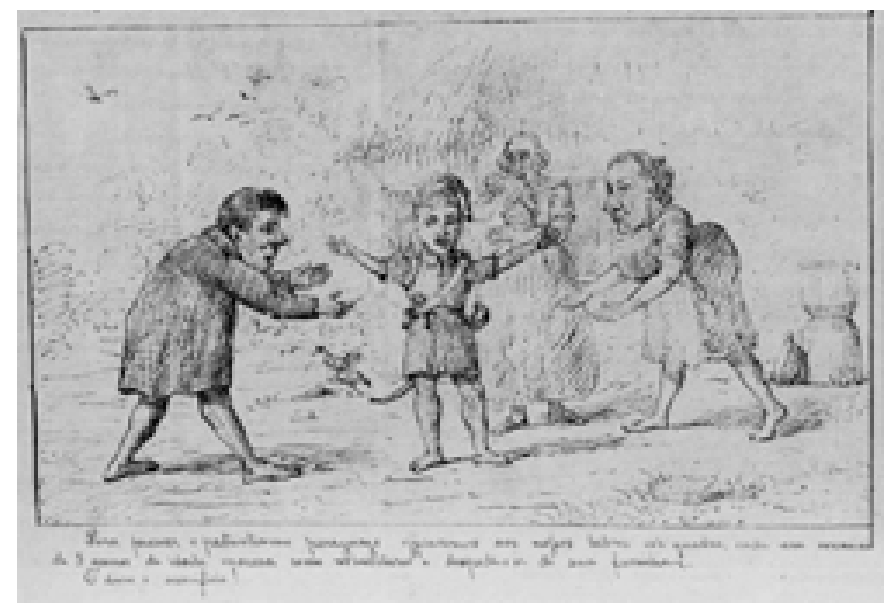

Paraguay Illustrado, No 5, 27 de agosto de 1865, p. 3 , . Hemeroteca Digital de la Biblioteca Nacional de Rio de Janeiro.

"Para probar el patriotismo paraguayo ofrecemos a nuestros lectores este cuadro, donde un niño de 5 años de edad marcha como voluntario y se despide de su familia. ¡Es duro el sacrificio!”.

La representación del pueblo paraguayo tiene protagonismo también en imágenes como la 5. En ella se observa una situación en la cual un niño está siendo enrolado para la guerra[11]. La escena enmarca a la que se supone sea su familia despidiéndose del infante de apenas cinco años, quien, voluntariamente se habría enlistado en el ejército. Se sugiere aquí, en primer lugar, que la niñez está siendo interrumpida por motivo de la guerray, por otro lado, los ejércitos paraguayos están formados por personas con poca preparación y para nada idóneas para estas labores, tales como los niños pequeños. En otro orden, la pobreza material se manifiesta en la ropa y carencia de zapatos de los personajes de la caricatura y la humilde casa que se encuentra en el segundo plano refuerza esta noción. La deformación de los cuerpos, sobresaliente en los que parecen ser los padres del niño guerrero llama poderosamente la atención. Éstos son dos personas de corta estatura, encorvados, con rostros poco armónicos y grandes zonas de pelos en sus narices. Además de su apariencia poco agraciada, la actitud moral de estos personajes que parecen estar alegres por el desafío de su pequeño hijo, se plantea como cuestionable.

\section{2 ¿Cómo es la alteridad chilena?}

Algunos años después, en pleno conflicto del Pacífico, El Barbero publica en su sexta edición una imagen en la cual hay una explícita oposición entre una configuración visual de la idea de Chile y una sobre Perú. Haciendo uso del recurso del cuerpo de la mujer como alegoría para significar la idea de República (Cornejo, 2006), el caricaturista (anónimo) compone dos cuerpos con características atribuibles a cada una de las naciones representadas que permite observar el contraste entre ellas. 
Imagen 6 - Las mujeres república

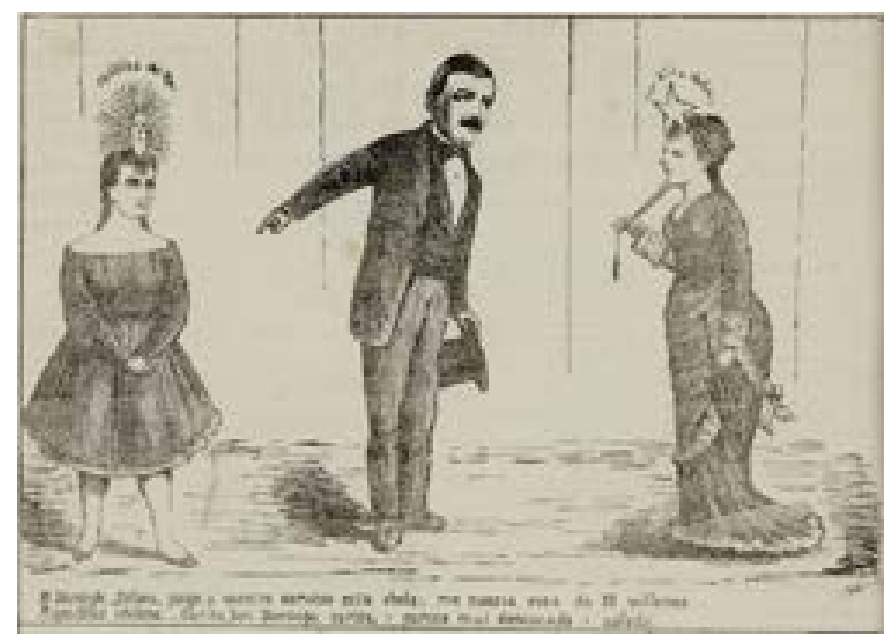

El Barbero, No 6, 29 de noviembre de 1879, p. 2, Biblioteca Nacional Digital de Chile

“D. Domingo - Señora, pongo a vuestro servicio esta chola; me cuesta cosa de 20 millones

República chilena - Carito, Don Domingo i parece mui descocada i zafada".

El tercer personaje en la escena es Domingo Santa María, futuro presidente de Chile (1881-1886), que en ese entonces se desempeñaba como ministro del Interior del gobierno de Aníbal Pinto. Vestido de traje y con su galera en la mano en señal de respeto a su interlocutora mujer-República de Chile, Santa María le ofrece a ésta el servicio de la "chola", como el la llama en el diálogo que complementa la imagen. La mujer ofrecida es la República de Perú y los representantes de Chile disponen de ella.

La mujer-República de Chile aparece con un elegante vestido del cual se destacan sus puños militares, y accesorios, como un abanico y una sombrilla, símbolos de actividades de ocio y placenteras, como un paseo. Su estilo es el de la moda europea burguesa. En su frente, se observa una estrella que ilumina y que podría ser una referencia a la que ostenta la bandera nacional. Enmarcando esta estrella, el rótulo "República de Chile" que no deja margen a la confusión sobre quien representa. Del lado opuesto de la imagen, la mujer-República de Perú, aparece con trajes típicos, una falda abultada que deja ver las partes inferiores de sus piernas y una blusa que muestra sus hombros. Su vestimenta es sencilla, no presenta los vuelos, caídas o puntillas que la ropa de la mujer que personifica a Chile. Su pelo está trenzado en a ambos lados de su cabeza y cae por su espalda. Su cara muestra unas cejas pobladas y en su frente, al igual que la estrella de la mujer de Chile, brilla un Sol y el rótulo "República del Perú”. En algún momento este elemento formó parte de las formas de identificación nacional peruanas[12].

La imagen establece una jerarquía entre ambas mujeres, mediada por la presencia y ofrecimiento del ministro de Estado. En primer lugar, la denominación de "chola", la indumentaria, el peinado, sugieren el origen indígena de la mujer-República de Perú. Esto contrasta directamente con la mujer-República de Chile, vestida a la moda europea. En ningún momento a lo largo de la narrativa construida a lo largo de su decena de ediciones El Barbero realiza una valoración positiva de la población indígena, sino más bien todo lo contrario. Por lo tanto, puede interpretarse esta construcción desde una estimación negativa de lo indígena, la 
cual es concordante con la máxima sarmientina de la época: la oposición de la civilización con la barbarie. Lo indígena es bárbaro y se opone a idea de civilización, que se identifica con Chile. Por otro lado, y además de los motivos étnicos, la relación jerárquica se expresa por la pasividad de Perú y la posición activa y con poder de decisión de Chile. La mujer civilizada rechaza a la chola, la cual fue ofrecida para estar a su servicio.

Imagen 7 - Las mujeres y La Puerta

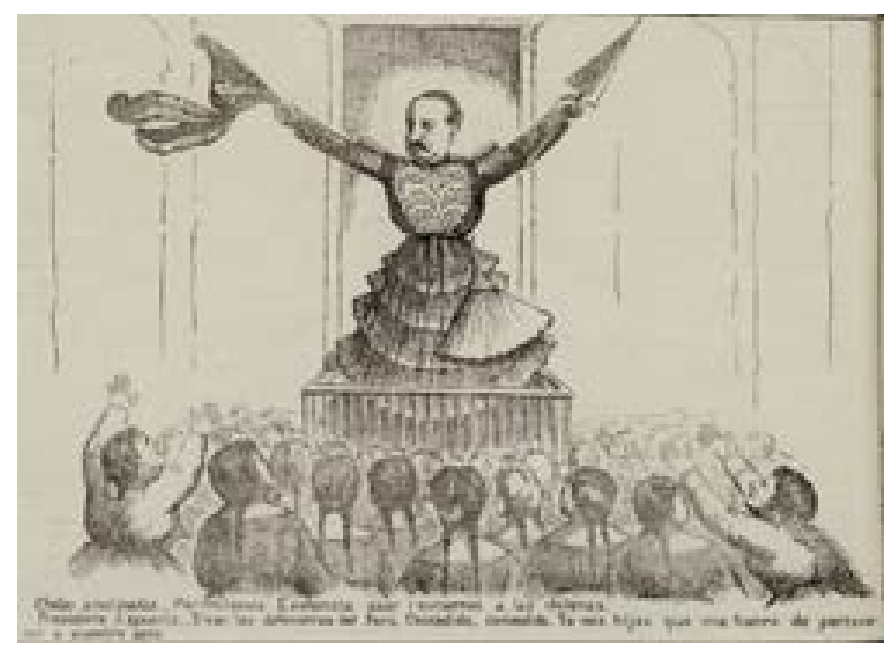

El Barbero, No 6, 29 de noviembre de 1879, p. 2, Biblioteca Nacional Digital de Chile

"Cholas amotinadas-Permitenos Excelencia asar i comernos a las chilenas.

Presidente Lapuerta - Vivan las defensoras del Perú. Concedido, concedido. Ya veis hijas que me honro de pertenecer a vuestro sexo".

En el mismo número, la Imagen 7, la chola peruana deja de ser forma de representación de una alegoría para convertirse en símbolo del pueblo. Uno de los asuntos tratados en esta edición en sus columnas textuales, es la supuesta irrupción de mujeres en la defensa del Perú, provocada por la debilidad de los hombres del ejército de esa nacionalidad[13], lo cual es categorizado por El Barbero como un síntoma de debilidad y ridiculez.

La imagen en concreto presenta una multitud de cholas, caracterizadas como la mujer que simbolizaba la república peruana en la Imagen 6. Todas ellas están reunidas al pie del balcón en el cual aparece Luis La Puerta, identificado como "Presidente Lapuerta" [14]. Este, parado, con sus brazos extendidos es caracterizado como mitad hombre militar, mitad mujer. En sus manos tiene un sombrero militar y en la otra una sombrilla de paseo; su tronco está vestido con uniforme militar y sus piernas se cubren con una amplia falda con grandes volados. Esta caricatura feminiza a la autoridad peruana quien se honra "de pertenecer a vuestro sexo" según se indica en la leyenda, expresión que se contradice con la pretendida virilidad castrense.

En el breve diálogo que acompaña la imagen, se expresa el motivo por el cual las "cholas" estarían reunidas en torno a La Puerta: le solicitan su permiso para "asarnos i comernos a las chilenas". Así, la imagen en conjunto con el texto apunta hacia la voluntad antropofágica de las mujeres peruanas. La sugerencia de una persona, o de un grupo como en este caso, con prácticas caníbales es un tópico recurrente para realizar un vínculo entre lo representado con lo salvaje, lo monstruoso y lo antihumano (Rojas Mix, 2015). En este caso, la monstruosidad de las peruanas se conjuga con la feminización de las autoridades, en un sentido 
peyorativo. Además de salvajes, presentan síntomas de debilidad que serían propios de las mujeres, en un momento donde la virilidad y la masculinidad son los valores marciales destacados por El Barbero.

\section{Imagen 8 -El remate}

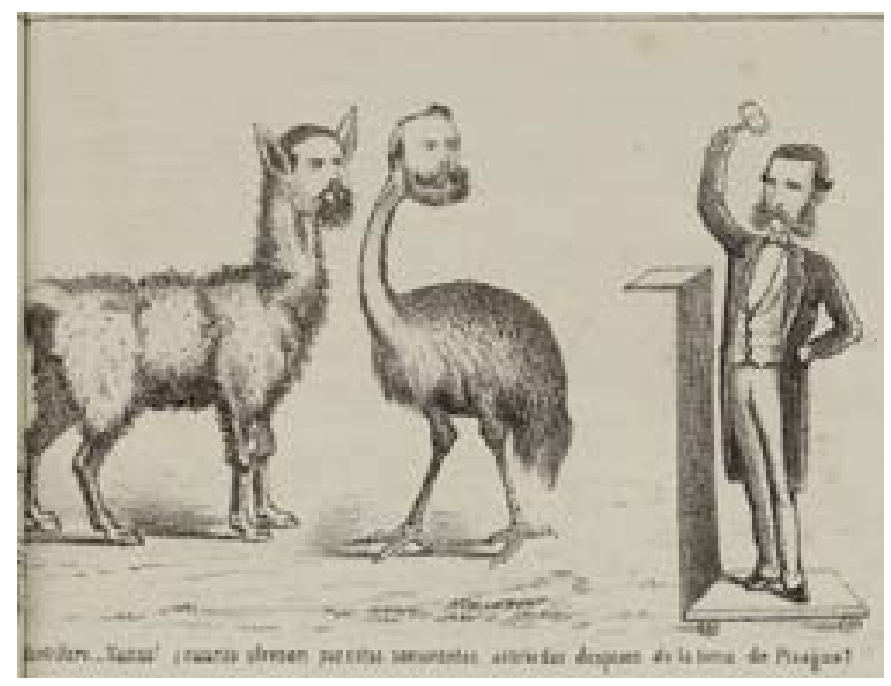

El Barbero, No 4, 15 de noviembre de 1879, p. 3, Biblioteca Nacional Digital de Chile

“Martillero - Vamos! ¿cuánto ofrecen por estos semoventes averiados después de la toma de Pisagua?".

Por último, en la Imagen 8, un rematador parado hacia la derecha está ofreciendo al mejor postor dos animales semovientes[15]. Éstos, tienen la particularidad de tener rostros humanos reconocibles: Hilarión Daza, presidente boliviano es la llama ubicada a la izquierda y Mariano Prado, presidente peruano, es el ñandú. El caricaturista hace uso en esta ocasión de la animalización de personas en conjunción con elementos retratísticos que posibilitan individualizar y asociar estos seres con personas específicas.

El motivo del remate de estos animales es que estarían averiados después de la toma de Pisagua, por lo tanto, su valor económico habría caído. En este caso, se hace una referencia directa a la ocupación chilena del territorio de Tarapacá que fue defendido por Perú y Bolivia a comienzos de noviembre de 1879 (Mellafe y Pelayo, 2018: 222). Al perder estos territorios, otrora peruanos, y ser ganados por Chile el potencial económico minero de estos países se habría visto mermado, considerando la zona rica en salitre que ya no estaba bajo su dominio que se sumaba a las anteriormente perdidas en los meses previos.

Además de la referencia directa a los sucesos más frescos de la guerra para ese entonces, El Barbero juzga y animaliza a los representantes políticos de los partidos enemigos de Chile en la contienda. El cuerpo de llama[16] de Hilarión Daza lo refiere directamente al espacio de donde este animal es originario: el altiplano andino. La conjunción del rostro de Prado, con un cuerpo de ñandú probablemente también se constituya como una referencia geográfica, pensando en que podría ser la variante cordillerana de esta especie (rhea pennatagarleppi). Al asociar personas con animales, las caricaturas despojan al representado de características propias de la naturaleza humana. La más distintiva es el pensamiento racional, por tanto, según esta imagen Prado y Daza estarían privados de esta cualidad. 


\section{Reflexiones finales}

A través de una breve selección de imágenes publicadas en periódicos satíricos en tiempos de guerra, pueden esbozarse algunas ideas de cómo se configura la idea de la alteridad, en términos de enemistad, al momento de la guerra.

Tanto en el caso brasileño como en el chileno, las caricaturas tuvieron una acción corrosiva frente a la imagen del enemigo. En todos los casos se los presenta como inferiores y para eso se hace uso de características que se entenderían en esta categoría, tales como la feminización, la pobreza material, lo indígena, la poca preparación guerrera, la irracionalidad, lo bárbaro y lo salvaje.

El Barbero y Paraguay Illustrado presentaron características únicas a cada publicación en relación con su contexto. Sin embargo, actuaron de forma similar en la manera de representar a los participantes de los conflictos con los cuales dialogaban. Ambos periódicos muestran una configuración de discurso sobre la guerra que requiere la objetivación de una alteridad que justifique la empresa bélica. La prensa satírica lo hizo visible y configuró a la otredad desde los valores disponibles en las sociedades locales a las cuales iban dirigidas sus representaciones.

La imagen de superioridad de Chile o Brasil que se desprende del mensaje emitido por cada una de las imágenes presentadas fue, por otro lado, una fuente o un recurso para generar una sensación de optimismo frente a la guerra. Si los otros contra los cuales se está peleando son menos que nosotros la guerra sería fácil y la victoria, inminente. Por lo tanto, las narrativas presentadas por la prensa satírica, al menos en estos momentos iniciales del conflicto, son funcionales al aliento nacionalista que la contienda requería.

En suma, al interpelar estas fuentes desde la pregunta del cómo plantearon o sugirieron una identidad nacional en términos de guerra, puede decirse que definieron a los otros como lo que nosotros no somos. No somos ignorantes, ni femeninos, ni bárbaros, ni salvajes, ni inhumanos. El nosotros es racional, masculino y viril, civilizado, con altura moral y preocupado con su gente. Más allá de las particularidades del caso brasileño y chileno estudiados, que sin duda deben completarse con mayor cruce de documentos, el breve análisis de este artículo buscó, entre otras cosas, haber aportado en la reflexión sobre la naturaleza y el comportamiento de las publicaciones periódicas satíricas con caricaturas decimonónicas en coyunturas bélicas.

\section{Referencias citadas}

\section{Periódicos}

Paraguay Illustrado (Rio de Janeiro, 1865). Hemeroteca Digital de la Biblioteca Nacional de Rio de Janeiro.

El Barbero (Santiago de Chile, 1879). Hemeroteca de la Biblioteca Nacional Digital de Chile.

\section{Libros y artículos}

Beretta García, E. (2012): “La litografía, la difusión de la imagen y su papel como herramienta propagandís- 
tica en Montevideo durante el siglo XIX", en Maronna (Ed.), Historia, culturay medios de comunicación. Enfoques y perspectivas, Montevideo, Biblioteca Nacional de Uruguay.

Capdevila, L. (2020): Una guerra total: Paraguay, 18641870. Ensayo de historia del tiempo presente, Buenos Aires, SB.

Castagneto, P. (2015): Corresponsales en campaña en la Guerra del Pacífico: 1879 - 1881. Santiago de Chile, RIL Editores.

Chartier, R. (2011): “Defesa e ilustração da noção de representação”, Fronteiras, 13(24), pp. 15-29.

Cid, G. (2011): “Arte, guerra e imaginario nacional: la Guerra del Pacífico en la pintura de historia chilena, 1879-1912", en Donoso y Serrano (Eds.), Chile y la Guerra del Pacífico, Santiago de Chile, Universidad Andres Bello, pp. 75-113.

Cornejo, T. (2006): “La República como mujer en los periódicos de Juan Rafael Allende: un discurso político en caricaturas (1875-1902)", Mapocho. Revista de Humanidades, 59, pp. 11-46.

Darnton, R. (2008): Los best sellers prohibidos en Francia antes de la revolución. Buenos Aires, Fondo de Cultura Económica.

Gombrich, E. (1998): "El arsenal del caricaturista”, Meditaciones sobre un caballo de juguete y otros ensayos sobre teoría del arte, Debate, pp. 127-142.
Ibarra, P. (2009): Caricaturas chilenas de la Guerra del Pacífico, 1879-1884. Tesis de Magíster, Universidad de Chile, Santiago de Chile.

Ibarra, P. (2016): "Peruanos y bolivianos en la sátira chilena de la Guerra del Pacífico (1879-1884)”, Historia y Comunicación Social, 21(1), pp. 75-95.

Johansson, M. L. (2017): La gran máquina de publicidad. Redes transnacionales e intercambios periodísticos durante la guerra de la Triple Alianza (1864-1870), Sevilla, Universidad Internacional de Andalucía.

Knauss, P., Malta, M., Oliveira, C., \& Pimenta, M. (2011): Revistas Ilustradas. Modos de ler ever no Segundo Reinado, Rio de Janeiro, Mauad X FAPERJ.

Matallana, A. (2010): Imágenes y representación. Ensayos desde la historia argentina. Buenos Aires, Aurelia Rivera.

McEvoy, C. (2012): “Civilización, masculinidad y superioridad racial. Una aproximación al discurso republicano chileno durante la Guerra del Pacífico (1879 - 1884)", Revista de Sociología Política, 20 (42), pp. 73-92.

Mellafe, R., \& Pelayo, M. (2018): La Guerra del Pacífico en imágenes, relatos y testimonios. Santiago de Chile, Legatum Editores.

Montealegre, J. (2008): Historia del humor gráfico en Chile, Lleida, Editorial Milenio.

Rojas Mix, M. (2015): América imaginaria. Santiago de Chile, Pehuén. 
Román, C. (2010): La prensa satírica argentina del siglo XIX: palabras e imágenes, Tesis de Doctorado, Universidad de Buenos Aires, Buenos Aires.

Román, C. (2016): “Diseños transnacionales. La prensa satírica en la Guerra de la Triple Alianza”, Literatura y Lingüística, 34, pp. 131-150.

Silva, R. de J. (2017): “La prensa ilustrada y la guerra en el siglo XIX: imágenes de los líderes de la Guerra de la Triple Alianza (1865 - 1870)", Cabichui, Cabrião y El Mosquito, Americania, 5, pp. 65-102.

Silveira, M. C. (2015): A batalha de papel: a charge como arma na guerra do Paraguai. Florianópolis: Ed. da UFSC.

Szir, S. (2009): “De la cultura impresa a la cultura de lo visible. Las publicaciones periódicas ilustradas en Buenos Aires en el siglo XIX”, en Imágenes, textos y contextos, colección Investigaciones de la Biblioteca Nacional, Buenos Aires: Teseo.

Toral, A. (2001): Imagens em desordem. A iconografia da Guerra do Paraguai, São Paulo, Humanitas.

Whigham, T., Brezzo, L., Ramírez, D., Fano, M., Doratioto, F., \& Casal, J. M. (2021): La Guerra Guazú. Conversaciones y reflexiones de historiadores extranjeros sobre la epopeya paraguaya, Asunción, Intercontinental Editora.

\section{Notas}

[1] Como dato ilustrativo, en 1879 "90 publicaciones periódicas de diversa índole existían [...] o aparecieron a lo largo de ese año. [...] Durante el tempo que duro la Guerra del Pacífico se publicó en Chile un total de 178 periódicos de todo tipo" (Castagneto, 2015: 18)

[2] Según Sandra Szir, cultura impresa se define como “corpus de objetos resultantes de la multiplicación técnica de textos a partir de la adopción de la imprenta, refiere no solo al objeto sino también a su empleo, difusión y recepción en los diferentes ámbitos de la vida política, social, cultural, educativa, científica o comercial." Estos materiales "acompañaron lsa transformaciones culturales, las luchas políticas, el asentamiento del Estado y sus distintos procesos de institucionalización" (Szir, 2009:15-16).

[3] Si bien Román sostiene esta afirmación para el caso de la Guerra de la Triple Alianza, sostengo que es operativa también para la Guerra del Pacífico.

[4] Beretta García informa que la litografía "basa su procedimiento en el empleo de materiales grasos como jabón y sebo. Dibujando con dichos materiales sobre la piedra, una vez humedecida, la tinta repartida sobre ella es repelida por la humedad, pero es retenida por los materiales grasos con los que se trazó el dibujo, [...] Colocando en la prensa la piedra entintada y sobre ella una hoja, se obtiene una serie de láminas impresas." (2012: 17).

[5] Probablemente esto se haya debido a una cuestión de disponibilidad de recursos económicos para producir el periódico, los cuales, tal como se manifiesta en el número 2, eran escasos: “Expondo ao público este insignificante trabalho, desde já pedimos venia, luttamos com grandes difficuldades, sobretudo a falta de recursos que uma tal empresa reclama. Entretanto a nossa boa vontade irá vencendo as difficuldades que nos embarcão. Assim o espermos. Assim o publico 
nos auxilie". (Paraguay Illustrado, n. 2, 6 de agosto de 1865, p. 1).

[6] Al menos en los fondos de la Hemeroteca de la Biblioteca Nacional de Chile no hay registro de esto.

[7] Por ejemplo, en Chile, El Combo (1878) contó con cinco números, La Penca (1868) con doce ediciones y El Chicote (1875-1876) doce números (Montealegre, 2008). En Brasil, publicaciones como Psit!!! (1877), O Besouro (1878-1879), O Arlequim (1867), entre otras, también fueron de corta vida (Knauss et al., 2011).

[8] Paraguay había ocupado la provincia argentina de Corrientes y tenía presencia en Uruguayana, Rio Grande del Sur, Brasil. Su objetivo era llegar a Uruguay.

[9] Las traducciones de pies de páginas son propias.

[10] Este artículo no se ocupará de la función que los textos cumplen al vincularse con las imágenes, tema central para investigar la naturaleza de estos periódicos satíricos con caricaturas. No obstante, se indicará al respecto de las formas que se configuran en algunos casos que van desde la explicación, la tensión, la ironía, la contradicción, hasta el complemento

[11] Si bien el enrolamiento de menores en el ejército dirigido por Solano López fue una realidad palpable en episodios como la Batalla de Acosta Nu (1869), no tenía lugar todavía en las instancias primarias del desarrollo del conflicto. Según informa Luc Capdevilla (2020), a pesar de las pérdidas paraguayas en términos de recursos humanos durante 1865, todavía el país disponía de hombres maduros para incorporar a sus ejércitos.
[12] El sol y la estrella, como elementos con brillo, podrían representar las ideas iluministas que forman la base del pensamiento republicano decimonónico.

[13] Esa información no ha podido ser cruzada con otras fuentes, hasta el momento, para saber si refiere a algún episodio puntual o si es una historia que El Barbero inventa para mofarse de Perú.

[14] Si bien Luis La Puerta era el vicepresidente de Perú, se hizo cargo internamente durante algunos meses, del gobierno mientras el titular de la presidencia, Mariano Prado, se encontraba cerca del frente de batalla.

[15] Semovientes son los animales que se pueden desplazar por sí mismos y que constituyen un patrimonio.

[16] La llama asociada a personajes bolivianos es un recurso que El Barbero utiliza también en otras caricaturas. Por ejemplo, en el número 8 se publica una imagen donde Narciso Campero habría llegado a Calama montado en llama. Campero asumió la presidencia de Bolivia en 1880, pero a finales de 1879 era militar del ejército. 